Chirurgia (2020) 115: 7-11

No. 1, January - February

Copyright@ Celsius

http://dx.doi.org/10.21614/chirurgia.115.1.7

\title{
The Man Behind Roux-En-Y Anastomosis
}

\author{
Carmen Naum¹, Rodica Bîrlăa,2, Cristina Gândea ${ }^{1,2}$, Elena Vasiliư', Silviu Constantinoiu ${ }^{1,2}$ \\ 'Carol Davila University of Medicine and Pharmacy, Bucharest, Romania \\ ${ }^{2}$ General and Esophageal Surgery Department, Center of Excellence in Esophageal Surgery, Saint Mary Clinical Hospital, Bucharest, Romania
}

Corresponding author:

Rodica Birla, MD

General and Esophageal Surgery

Department, Center of Excellence

in Esophageal Surgery, Sf. Maria

Clinical Hospital, Bucharest, Romania

E-mail: birlarodica@ahoo.com

\section{Rezumat}

Omul din spatele anastomozei Roux-în-Y

César Roux (1857-1934) s-a născut în satul Mont-la-Ville din cantonul Vaud, Elveția şi a fost cel de-al cincilea fiu, dintre cei 11, ai unui inspector şcolar. A studiat medicina la Universitatea din Berna şi i-a avut printre profesori pe Thomas Langhans în patologie şi pe Thomas Kocher în chirurgie. Roux, la fel ca mulți chirurgi din acea perioadă a practicat chirurgia ginecologică, ortopedică, generală, toracică şi endocrină, dar a devenit celebru în chirurgia viscerală. El a dominat toate domeniile chirurgicale şi a influențat chirurgia cu spiritul său inovator, dar contribuția sa cea mai mare a fost anastomoza Roux-în-Y. Fiind un chirurg meticulos, dar care în acelaşi timp, opera repede, o persoană muncitoare, dedicată pacienților şi studenților săi, el şi-a găsit un loc în istoria medicinei. A murit în 1934, iar moartea sa bruscă a fost un motiv de doliu național în Elveția.

Cuvinte cheie: Roux, César Roux, Roux-în-Y, gastroenterostomy, istoria chirurgiei

\section{Abstract}

César Roux (1857-1934) was born in the village of Mont-la-Ville in the canton of Vaud, Switzerland and he was the fifth son, among 11 children, of an inspector of schools. He studied medicine in the University of Bern and he had among his mentors Thomas Langhans in pathology and Thomas Kocher in surgery. Roux, as many surgeons of that time performed gynecologic surgery, orthopedic surgery, general surgery, thoracic surgery and endocrine 
surgery, but he became famous in visceral surgery. He dominated all fields of surgery and influenced current surgery with his innovative spirit, but his biggest contribution to surgery was Roux en Y anastomosis. His nature of meticulous but in the same time swiftly surgeon, hard working person, dedicated to his patients and students found him a place in history of medicine. He died in 1934 and his sudden death was reason for national mourning in Switzerland.

Key words: Roux, Cesar Roux, Roux-en-Y, gastrojejunostomy, surgical history

\section{Introduction}

Cesar Roux was a pioneering and versatile Swiss surgeon who played a decisive role in the surgical evolution at the end of the $19^{\text {th }}$ century and the beginning of the $20^{\text {th }}$. During the 36 years of his professorship he became one of the outstanding surgeons of Europe by using an original surgical technique (1).

The personality and history of Professor César Roux are part of world medical and surgical heritage (1).

The aim of this study is to present the life of César Roux and his contribution to modern surgery and to illustrate the development of his reconstruction technique.

\section{Family, Childhood and Education}

César Roux was born on Monday, March 23, 1857 in Lémanique Région, in the village of Mont-la-Ville, canton of Vaud, Switzerland (2).

$\mathrm{He}$ was the son of Benjamin Roux and Jeanne Louise Courvoisier, who had French origins and they emigrated to Switzerland during the seventeenth century (2). At that time, adversity for French refugees was big. In fact, just a few years after the birth of César Roux, almost a century after the first French immigration to Switzerland, these families received Swiss citizenship (1).

César Roux was the fifth son, among 11 brothers and he grew up in a middle-class family in terms of financial resources (3).

His father, who is mentioned as a teacher, but he also worked as a school inspector, was the initial counselor in the study and education of the young César (4).
After graduating primary school, in Montla-Ville, in his native village, Roux continued his studies at the cantonal college in 1868 and from 1874 at the Lausanne high school, which he successfully completed in 1875 (5).

The young Roux showed leadership qualities from 1873, when he was promoted to lieutenant in the Cadet Corps and in addition to school, he also performed military exercises (1).

At first, he aspired to a career as a veterinarian, but when he was told that in order to practice this profession, he would have to appear in formal outfits, wearing a hat with a stove pipe shape, he changed his option and he chose to study human medicine (3).

After his father's death in 1876, his family supported him in financing his medical school (1).

He began medical studies in Bern in October 1876, where he trained with Christoph Theodor Aeby and Theodor Langhans. After graduating in 1880, he worked at the Bern Hospital, under the leadership of Emil Theodor Kocher, the future winner of the Nobel Prize (first Nobel laureate surgeon for medicine in 1909, for thyroid surgery) (5).

Under Kocher's guidance, he composed his doctoral thesis in German in 1880 on "Contributions to the knowledge of human muscles". After successfully completing his state exam, Kocher offered him a position as a surgical assistant at Bern Island Hospital (1).

During this time, he visited surgeons Theodor Billroth (1829-1894) in Vienna and Richard von Volkmann (1830-1889) in Halle (6).

In 1883, eager to reimburse his brothers and sisters who funded his studies, he moved 
to Lausanne, in a working-class district as a general practitioner. Roux, being a man who acted with caution, he started his activity with small outpatient surgery (7).

In 1884 he married Anna Begoune from Kherson (Russia, now Ukraine) also a physician, and they had two children, Suzanne (born on September 26, 1887) and Hélène (born on March 21, 1893) (5).

Roux didn't have electricity, or phone, or operating room. With the help of his wife, Anna, between two consultations for angina or pneumonia, he performed surgical operation in his home (8).

Roux was only a young doctor when he was appointed head of surgical department in Vaud Cantonal Hospital, on March 1, 1887 (8).

In addition, he taught forensic medicine at the Academy. He was also, a member of the committee responsible for studying the transformation of the Academy into a university and, when the Lausanne School of Medicine was founded in 1890, César Roux, at the age of 33, became teacher of external pathology and gynecology. He was appointed associate professor of surgery in 1890, and then a full professor in 1892. He became the first full professor in surgery (5).

\section{Surgeon and Pioneer}

For a long time, almost until the early 1880s, the surgeons were a small, very young, professional group. The abdominal cavity remained taboo for a long time, almost inaccessible before the development of asepsis and narcosis (7).

Surgery was a mystery rather than a science, based on empiricism and pragmatism, practiced by pioneering enterprises. The operative mortality was too high, and the anesthetic accidents were too numerous (1).

At the beginning of his professional career, Roux was enthusiastic about the progress and technical improvement of the surgical interventions, but in time he became more and more limited to smaller and less traumatic surgeries, which had much better results (1).

The development of surgery from the late 19th to early $20^{\text {th }}$ centuries was decisively modeled by César Roux, who became involved in daring enterprises for the $19^{\text {th }}$ century when technological progress was high in the scientific, industrial and socio-economic fields (9).

The operative medicine, as surgery was called in those days, has blossomed suddenly, as has never happened before, due to scientific discoveries and their applications, including the development of anesthesia and hygiene, increasing the field of knowledge in physiopathology, pre and postoperative care and the use of antiseptic and aseptic methods (9) promoted by Ignac Füllop Semmelweis, Joseph Lister and Louis Pasteur, and in our country by Professor Constantin Dimitrescu-Severeanu and Professor Constantin Angelescu (10).

Roux handles all areas that were accessible to surgery at that time: orthopedic, urological and gynecological and thoracic surgery (11).

He was also involved in the treatment of gout, pulmonary tuberculosis and in 1926, he performed the first surgery to remove a pheochromocytoma and he described procedures for hemorrhoids, rectal prolapse, inguinal hernia, prostatectomy, and osteomyelitis (11).

He studied the problem of appendicitis, which at that time was called peritiflitis (4). His greatest contribution to surgery, the reason why he was mentioned in countless operating rooms everyday, is known as "Roux-en-y". César Roux left his name of a digestive surgery, called Roux-en-Y anastomosis, a by-pass surgery of the digestive tract using segments of the small intestine anastomosed (4).

\section{Roux-en-Y Anastomosis}

The idea of Y loop probably belonged to Socin or Wolfler, but none of these surgeons performed the procedure (9).

Although at the time, medicine was a rudimentary one, with no radiological examination to make the preoperative diagnosis, in 1892 , Roux performed for the first time "Roux-en-Y anastomosis" as a treatment for gastric outlet obstruction. He sectioned the jejunum at 15-30 $\mathrm{cm}$ distal to the ligament of Treitz, anastomosed the distal end to the stomach, and the 
proximal end (afferent or biliopancreatic loop) to jejunum at $10^{-12} \mathrm{~cm}$ distal to gastrojejunostomy (12).

César Roux called this type of operation "posterior transmesocolic gastroenteroanastomosis by implantation" and continued to use it, avoiding the risks of other gastroenteroanastomosis procedures (1).

The mortality rate for the first group of 50 patients was $30 \%$, which was considered reasonable for that period (9).

Roux followed the patients he operated on for the long term, and in patients with malignancies he reported an average survival of 7.5 months. In patients operated for benign pathology, he observed in $50 \%$ of these patients the development of marginal ulcers on the jejunal side of gastrojejunostomy (12).

Roux followed his patients on a long-term basis and reported an average survival of 7,5 months in patients with malignancies. In patients with benign pathology, he observed the development of marginal ulcers on the jejunal side of the gastrojejunostomy, that appeared in $50 \%$ of these patients (12).

Because of the major rate of marginal ulcer, this surgical technique was abandoned, prompting Roux's assistants to state that "it is a procedure that is no longer used today" and it was omitted from the writings of the first half of the 20th century (Orr, Thorek, Spivak, Shackelford) (11).

However, in the 1950s, the Roux loop began to be used, with very important indications: reconstruction following partial or complete gastrectomy for stomach cancer, multiple failed Nissen fundoplication surgeries, internal drainage of the pseudocysts of the head of pancreas, drainage of pancreatic stump after cephalic duodenopanreatectomy, biliary drainage in distal stenoses of the main bile duct, treatment of congenital choledochal cyst, complicated duodenal trauma, and since 1977 in the treatment of obesity as gastric by-pass (13). At present, to reduce the incidence of marginal ulcer Y-loop is preceded by vagotomy and for the prevention of Roux stasis syndrome an enlarged gastrectomy is used. Also, in order to prevent biliary reflux in the stomach, the length of the food loop should be $50-60 \mathrm{~cm}$, and to prevent malabsortion, the biliary loop will be $20 \mathrm{~cm}$.

\section{Retirement}

In 1926, after 36 years of his career, Cesar Roux returned to private practice. He died at the age of 77 , on December 21, 1934, after a heart attack, while he was consulting a patient and he was buried at Sainte Croix. His death was considered a day of national mourning (2). His successor, Professor Pierre Decker, said that Roux was "king of the scalpel, one of the fifty most famous surgeons in Europe" (8).

\section{Awards}

César Roux was decorated Knight of the Legion of Honor of France, commander of the order of George I, Grand Officer of the Order of the Crown of Italy and honorary president of the Swiss Society of Surgery (5).

He received the title of member of many foreign companies of surgery and medicine. He was a member of the French Congress of Surgery, a correspondent member of the Surgical Society of Paris, a member of the French Association of Urology, a correspondent member of the Military Academy of Medicine in Saint Petersburg, a foreign associate member of the Paris Academy of Medicine (4).

Among his awards and prizes obtained are the following: Doctor Honoris Causa at the University of Chicago, Doctor Honoris Causa at the Sorbonne University, Doctor Honoris Causa of the University of Bern on November 10, 1929, Honorary member of the city of Lausanne on April 7, 1903, Citizen of honor in his native village on November 27, 1908 (5).

César Roux has a carved image in the courtyard of the Cantonal Hospital in Lausanne, created in 1947 by Casimir Reymond and a street in Lausanne was named after him (5). The University of Lausanne is currently granting every year an award named after César Roux to a young doctor (5). 


\section{Conflict of Interest}

All authors declare that they have no conflict of interest.

\section{References}

1. Dhayat S, Renggli JC, Dhayat N, Merlini M. Zum 150. On the $150^{\text {th }}$ Birthday of César Roux (1857-1918). Memories of the Life and Work of an Important Pupil of Kocher. Chirurg. 2007;78(2):155-60. German

2. Kaba M. César Roux (1857-1934). Dictionnaire historique de la Suisse, 10. 2011.

3. Haubrich WS. Roux of the Roux-en-Y Anastomosis. Gastroenterology. 2004;126(3):653.

4. Martínez M, Reyes Devesa G, Reyes Devesa HE. César Roux. El cirujano y su anastomosis. Cirujano General. 2005;27(2):171-175.

5. César Roux. Wikipédia, I'encyclopédie libre. Page consultée le
17:35, janvier 2, 2020 http://fr.wikipedia.org/w/index.php?title= C\%C3\%A9sar_Roux\&oldid=165960689.

6. Mason GR. Perspectives a century later on the "Ansa en $Y$ " of César Roux. Am J Surg. 1991;161(2):262-5.

7. Mudry A. César Roux (1857-1934) et la gastro-entérostomie en Y. Forum Médical Suisse. EMH Media.2014;14:38.

8. Taillens J, Decker P, César Roux, son époque et la nôtre, Frédéric Saegesser Editions de l'Eglise nationale vaudoise,1989.

9. Besson A. The Roux-Y loop in modern digestive tract surgery. Am J Surg. 1985;149(5):656-64.

10. Sârbu V, Constantinoiu S. Prof. Constantin Dimitrescu-Severeanu: Our Father and Contemporary. Chirurgia (Bucur). 2017;112(1): 7-11.

11. Hutchison Richard L, Hutchison AL. César Roux and his original 1893 paper. Obes Surg. 2010;20(7):953-56.

12. Decker P. Considerations theoriques a propos de l'ulcers postgastro-enterostomies. Schweiz Med Wochenschr. 1936;66:73-86.

13. Deitel M. César Roux and his contribution. Obes Surg. 2007; 17(10):1277 